\title{
Auditors and Relationship Banking
}

\author{
Timothy Hinkel ${ }^{1}$ \\ ${ }^{1}$ Ashland University, USA \\ Correspondence: Timothy Hinkel, Ashland University, USA. E-mail: thinkel@ashland.edu
}

Received: July 10, 2019

Accepted: August 24, 2019

Online Published: August 25, 2019

doi:10.5430/afr.v8n3p219

URL: https://doi.org/10.5430/afr.v8n3p219

\begin{abstract}
This study examines whether a bank's relationship with a borrowing firm's external auditor through a shared client portfolio affects loan pricing. I find that when lenders' portfolios are more concentrated in firms engaging a particular auditor, borrowers who engage that auditor enjoy lower spreads. This relation is only evident when the lender is the lead arranger who is primarily responsible for information gathering about the borrower. Tests suggest the reduction in information asymmetry facilitating these lower borrowing costs occurs via banks' enhanced ability to interpret the audited financial statements when they have greater familiarity with the external auditor. My results are relevant to debt-seeking firms who should be mindful of their auditor's relationship with prospective lenders, as well as regulators seeking to better understand how auditors can affect corporate financing outcomes.
\end{abstract}

Keywords: auditors, bank loans, loan pricing

\section{Introduction}

How lenders collect and interpret relevant information about a borrower's creditworthiness in order to set prices remains an important question in a competitive loan market. "Relationship" banking provides one avenue for lenders to efficiently gather this information and offer a competitive price to the borrower. Traditional "relationship" banking purports that deeper relationships between the lender and borrower help overcome information asymmetries in the debt market and lead to lower borrowing costs (Elyasiani \& Goldberg, 2004). In this study, I consider whether the lender's relationship with the borrower's external auditor through a shared client portfolio is also associated with lower cost of debt for the borrowing firm.

Auditors are uniquely positioned to provide relevant information that may affect their clients' borrowing costs. While extant literature suggests banks incorporate information contained in the auditor's report into loan pricing (Chen, He, Ma, \& Stice, 2015; Kim, Song, \& Zhang, 2011), I consider whether banks appear to acquire or interpret information not overtly visible in the auditor's report or financial statements.

When banks more frequently issue loans to client-firms engaging a particular auditor, they may become more familiar with the auditor's "style" and hence the properties of the client-firm's earnings (Francis, Pinnuck, \& Watanabe, 2014). Further, they may gain a better understanding of the earnings information content of other prospective borrowers that also engage that same auditor. The relationship between the bank and auditor stemming from the two parties' shared client portfolio can thus reduce the information risk within a client-firm's financial reporting system and lead to a lower cost of debt for the client-firm.

By frequently dealing with clients who use a particular auditor, loan officers may also forge relationships with personnel from that audit firm. This may allow the lender to develop a deeper sense of trust in the auditor's report or audited financial statements that similarly reduces monitoring costs. Moreover, that relationship may involve an exchange of information beyond what is conveyed in the auditor's report or financial statements. Auditors acquire an intimate knowledge of their client's operations, opportunities, and risks in conducting their work. To the extent they are more likely to communicate these details to a lender with whom they share a client portfolio, the lender can expend fewer resources collecting client-information. This reduction in information gathering costs could also translate to a lower cost of debt for the client-firm.

Extant literature provides examples of direct relationships between a bank and the borrowing firm itself that can facilitate lower borrowing costs (Bharath, Dahiya, Saunders, \& Srinivasan, 2011; Sisli-Ciammarra 2012; Engelberg, Gao, \& Parsons, 2012). In these contexts, repeated lending occurrences or banker-manager affiliations alleviate information asymmetries that lower the cost of debt. I seek to build on this literature by considering whether a bank's 
relationship with an external intermediary can similarly reduce borrowing costs via a reduction in information asymmetries.

My research design tests whether a borrowing firm's spread is decreasing in the lender's loan portfolio concentration with the firm's external auditor. I alternatively consider concentration based on the amount or number of loans. For instance, if Firm A engages Auditor Q and has a loan with Bank X, I am interested in whether the fraction of Bank X's portfolio that engages Auditor Q affects Firm A's cost of debt. I hypothesize that as Bank X's portfolio of clients engaging Auditor Q increases, Firm A will enjoy lower borrowing costs via the shared client portfolio between its bank and auditor. In other words, I test whether the borrowing firm's bank-auditor concentration, which I term BAC_Amount or BAC_Count, will be negatively associated with the client-firm's borrowing costs, Spread.

The results support my hypothesis that borrowers enjoy lower loan spreads when lenders' portfolios become increasingly concentrated in other firms engaging the borrower's auditor. For instance, a six (five) percent increase in BAC_Amount (BAC_Count) is associated with a 1.5 (1.7) basis point reduction for the borrowing firm. For the average loan in our sample, this corresponds to roughly $\$ 73,500(\$ 83,300)$ annual savings in interest (i.e. $\$ 490$ million $\mathrm{x} 1.5$ (1.7) basis points). This association is apparent only when the lender is the lead arranger, the party primarily responsible for collecting information about borrowers and monitoring them. I do not find a significant association between bank-auditor concentration and borrowing costs when the lender is not a lead arranger, but find that a six (five) percent increase in BAC_Amount (BAC_Count) is associated with a 3.2 (3.2) basis point reduction for the borrowing firm. For the average lead arranger loan in the sample, this corresponds to roughly $\$ 131,840$ annual savings in interest (i.e. $\$ 412$ million x 3.2 basis points). Overall, the results provide evidence as to how shared client portfolios between banks and external auditors can alleviate information asymmetries between the borrowers and lenders.

In additional analysis, I try to assess whether the observed relation can be explained by banks directly soliciting private information from the external auditor at the local level; however, I do not find a significant relation between the variable of interest and client-firm borrowing costs when measuring the bank-auditor concentration as the percentage of a bank's client-portfolio engaging a specific auditor-office, where I would expect relationships between bank and audit personnel are most likely to manifest. Although I acknowledge private information sharing may be taking place that the specification and data does not enable us to observe, it is also possible that the lower spreads stem from banks' ability to more reliably interpret the information within a client's financial statements when they are more familiar with the "style" of the client's auditor at a national level.

This study provides unique contributions to both the relationship banking and audit literature streams. With respect to relationship banking, this is the first study, to my knowledge, that provides evidence as to how relationships between the lender and a client-firm's external auditor can impact the client-firm's cost of debt. This finding is relevant to debt-seeking client-firms, who should be aware that they may obtain more favorable loan pricing when the lender's client portfolio is more concentrated in firms sharing their external auditor. Further, it should encourage researchers to consider other shared relationships that transpire throughout the economy that affect a firm's financing.

With respect to audit, I build on the literature stream discussing consequences of shared auditors (Cai, Kim, Park, \& White, 2016; Dhaliwal, Lamoreaux, Litov, \& Neyland, 2016; Johnstone, Li, \& Luo, 2014; Ton 2015). I introduce a novel measure capturing the concentration of a bank's portfolio in client-firms sharing the borrower's external auditor and document how this bank-auditor concentration affects a borrowing firm's cost of debt. Importantly, when a bank and auditor share a sizeable client portfolio, it does not imply the bank engages that auditor for its own financials. This finding is relevant to researchers and regulators seeking to understand how auditors can affect corporate financing outcomes. To date, the literature has only considered reputation and expertise as auditor attributes that affect client-firm borrowing costs (Kim, Song, \& Tsui, 2013; Li, Xie, \& Zhou, 2010; Lou and Vasvari 2013; Mansi, Maxwell, \& Miller, 2004; Pittman and Fortin 2004). I demonstrate that an auditor's client portfolio in relation to the lender's portfolio can also significantly affect client-firm's cost of debt. Moreover, although the data do not enable me to test whether bank-auditor relationships affect the likelihood of lending, the lower borrowing costs auditors help facilitate suggest they are an important player in matching lenders and borrowers in the debt market. Lastly, I extend Francis et al. (2014) and respond to their call for further research on the implications of auditor style on the quality and informativeness of earnings.

The remainder of this paper proceeds as follows. Section 2 reviews prior literature and develops the hypothesis, Section 3 outlines the data and sample selection procedure, Section 4 describes the methodology and presents results, and Section 5 concludes. 


\section{Literature Review and Hypothesis Development}

\subsection{Relationship Banking}

Relationship banking theorizes that increased familiarity between a lender and borrower can reduce information asymmetries between the two parties and lead to more favorable terms for the borrower. Focusing on small firm finance, Berger and Udell (1995) find that borrowers with longer banking relationships pay lower interest rates. Meanwhile, Bharath et al. (2011) document that repeated borrowing from the same lender translates to smaller loan spreads. The results support the theory that stronger relationships between a lender and borrower can mitigate the adverse selection and moral hazard in the debt market.

More recent studies explore how relationships between personnel at the lending and borrowing institutions facilitate lower borrowing costs. Sisli-Ciamarra (2012) documents that firms with a lender-representative on their board of directors borrow at lower rates. Engelberg et al. (2013) find that firms pay lower interest rate when their managers have more personal connections, such as college attendance or previous work experience, with their bank's managers. These studies illustrate how direct, individual relationships between lenders and borrowers can improve information exchange and monitoring.

There is less evidence as to how indirect relationships, such as shared bank-auditor portfolios, can reduce information asymmetries and lead to more favorable financing.

Ivashina and Kovner (2011) present evidence of shared client portfolios leading to lower borrowing costs in a private-equity setting. They find that borrowers in a private equity firm's portfolio pay lower interest rates when the private equity sponsor has repeated transactions with the lending bank. The authors suggest the bank's relationship with the private equity sponsor reduces information asymmetries that allows for favorable loan terms for the portfolio firm.

Unlike private equity firms, who have an ownership stake in their portfolio and directly benefit by exchanging information that reduces loan spreads, external auditors are an independent intermediary who are restricted from sharing confidential client information under Section 301 of the AICPA Code of Professional Conduct, titled Confidential Client Information. (Note 1) This rule states that 'a member in public practice shall not disclose any confidential client information without the specific consent of the client.' CPAs who break the AICPA Code of Professional Conduct are subject to admonishment, suspension, or even expulsion from the AICPA and/or applicable state CPA society. Therefore, it is uncertain whether the relationship that exists between banks and auditors via shared client portfolios will be associated with the same favorable loan pricing that manifests when banks have a relationship with the borrowing firm's private equity sponsor. I discuss the literature related to shared auditors in the next section.

\subsection{Shared Auditors}

Although there are explicit prohibitions on auditors sharing confidential client information, extant literature suggests auditors do transfer knowledge within their client network. In the merger and acquisition setting, Dhaliwal et al. (2016) find that bid likelihood and deal completion rates are higher when the bidder and target share the same auditor. The authors infer that the common auditor communicates information about the target that reduces the bidder's information asymmetry. Relatedly, Cai et al. (2016) find that common auditors are associated with higher quality mergers and higher acquisition announcement returns. Johnstone et al. (2014) find that shared-auditors in supply-chain relationships improve audit quality for the supplier client and charge them lower fees, reflecting auditors' ability to transfer knowledge within a supply chain. In a bank setting, Ton (2015) shows that audit quality improves when a lender and borrower share the same auditor. Her evidence indicates that lenders who share an auditor office with their borrowers have more accurate loan loss provisions, while borrowers who share an auditor office with their lender are less likely to receive a clean audit opinion prior to bankruptcy. These studies highlight that despite explicit prohibitions on sharing confidential client information, shared auditors appear to transfer client-specific knowledge in order to reduce information asymmetries. While these studies suggest auditors transfer knowledge internally within their own client network, I consider whether auditors transfer knowledge externally to lenders who service their client network.

\subsection{Auditors and Cost of Debt}

Studies examining auditors' impact on their clients' cost of debt typically focus on attributes of the auditor or its report. For instance, firms engaging Big-N auditors or industry experts, common proxies for higher auditor quality or reputation, typically enjoy lower borrowing costs (Pittman and Fortin 2004; Kim et al. 2013; Lou and Vasvari 2013; $\mathrm{Li}$ et al. 2010). These studies posit that the higher quality auditors enhance the credibility of the underlying financial 
statements, thus reducing information asymmetries between the lender and borrower. Studies examining content within the auditor's report find that firms receiving a going concern opinion or material weakness over internal controls pay higher interest rates from banks (Chen et al. 2015; Kim et al. 2011). This suggests that banks incorporate publicly available information provided by auditors assess a borrower's risk. This study contemplates whether banks incorporate less transparent information from the auditor to reduce information asymmetries between themselves and the borrower.

\subsection{Hypothesis Development}

I acknowledge there are two mechanisms through which a bank can acquire information from an auditor with a shared client portfolio. First, its relationship with the auditor via a shared client portfolio may enhance its ability to directly solicit information about the client firm directly from the auditor. In this context, the shared auditor transfers client-specific knowledge to the bank, reducing the information asymmetry and facilitating lower borrowing costs for the client-firm.

Alternatively, the bank's relationship with the auditor via a shared client portfolio may enhance its ability to interpret the underlying properties of the borrowing firm's financials. Francis et al. (2014) document that comparable firms that share an auditor have more similar accounting accruals and earnings structure than those that engage different auditors. The authors suggest auditors have a unique "style," reflective of the internal working rules they use to implement auditing and accounting standards. This, in turn, affects the output of their clients' financial reporting. Banks whose clients are more concentrated within a particular auditor's portfolio may develop a better understanding of that auditor's style, which could facilitate their interpretation of the financial reporting output and reduce uncertainties that exist within the client's accounting.

I hypothesize that the existence of either of these effects- direct private information sharing or indirect interpretability of the financials- enables lenders to offer lower rates when their client-portfolio is more concentrated in firms engaging the same auditor as the borrower.

Hypothesis: A borrowing firm's loan spread is negatively associated with the percentage of the lender's client-portfolio that engages the borrowing firm's auditor.

\section{Data and Sample Selection}

The sample covers public firms that receive bank loans from 2000-2011. I begin the sample in 2000 because we identify a borrowing firm's auditor through Audit Analytics, which generally does not contain this information prior to 2000. Data on the pricing and characteristics of syndicated private loans including some borrower and lender characteristics are gathered from DealScan. Following Bharath, Sunder, \& Sunder (2008), I only include term and revolver loans with maturities greater than one year and seniority to claims on the borrower's assets. Since the research question focuses on the effect of the lender's relationship with the borrower's auditor, the primary analysis is at the borrower-lender level for each loan made. The data contains both syndicated and single bank loans. While syndicated loans may have multiple participating lenders, I limit my sample to lenders that have the greatest influence on loan pricing by restricting our sample to borrower-lender observations where the lender received either agent or arranger credit for making the loan. I merge the loan information with the borrower's auditor information from Audit Analytics and additional financial information from Compustat, which is used to construct control variables.

To measure the relationship between a given borrowing firm's lender and auditor, I construct two different measures of bank-auditor concentration based on the weighted percentage or total percentage of the lender's clients that use a given auditor. Following Ivashina and Kovner (2011), who measure the relationship a borrowing firm's lender and private equity sponsor over a five-year period, I similarly measure the relationship between a borrowing firm's lender and auditor over a five year period beginning in year t-4 and ending in year t. BAC_Amount calculates bank-auditor concentration as the sum of loan proceeds of all borrowers from a given bank $(k)$ using a specific auditor $(l)$ divided by the sum of loan amounts of all borrowers for that bank over a trailing five year period:

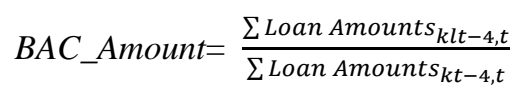

BAC_Count calculates the number of borrowers from a given bank $(k)$ using a specific auditor $(l)$ divided by the total number of borrowers for that bank over a trailing five year period:

$$
\text { BAC_Count }=\frac{\sum \text { Loans }_{k l t-4, t}}{\sum \text { Loans }_{k t-4, t}}
$$


For each loan $i$, auditor $l$ is defined as borrower $j$ 's current auditor. BAC_Amount and BAC_Count measure the strength of the relationship between the lender and the borrower's auditor. Higher levels of the bank-auditor concentration measure suggest a stronger relationship between the lender and the borrower's auditor. In other words, as the percentage of a bank's loans whose borrowers use the same auditor increases, the more frequently that bank will be interacting with a specific auditor, their staff, and their audit output. This, in turn, would lead to a stronger relationship between a bank and an auditor.

Although I scale our measure of bank-auditor concentration by the number loans or asset value of the bank's portfolio, the measures may be inaccurate for lenders that make too few loans. Thus, I require that lenders make at least 10 loans, on average, per year over the past five years to be included in the primary analysis. I further require that the observations represent loans of at least $\$ 10$ million in order to ensure they are economically meaningful. The final sample, after deleting observations missing control variables, contains 21,517 borrower-lender observations, representing 5,517 different firms in all 12 different Fama-French industries.

\section{Methodology and Results}

\subsection{Model Specification}

To test the primary hypothesis, I rely on the following regression specification:

$$
\begin{gathered}
\text { Spread }_{i j t}=\beta_{0}+\beta_{1} \text { AudConc }_{j k t}+\beta_{2} \text { NatExpert }_{j t}+\beta_{3} \text { Big4 }_{j t}+\beta_{4} \text { Size }_{j t}+\beta_{5} \text { LoanAmt }_{i t} \\
+\beta_{6} \text { Maturity }_{i t}+\beta_{7} \text { Security }_{i t}+\beta_{8} \text { Miss_Sec }_{i t}+\beta_{9} \text { BookLev }_{j t}+\beta_{10} \text { ROA }_{j t}+\beta_{11} \text { SNP }_{j t} \\
+\beta_{12} \text { Miss_SNP }_{j t}+\Sigma \gamma_{1-12} \text { IndFE }
\end{gathered}
$$

The dependent variable Spread measures the interest rate that borrower $j$ pays on the loan $i$ in year $t$, calculated in basis points and corresponding to the total cost paid over LIBOR for each dollar borrowed under the loan contract. (Note 2) AudConc is the auditor concentration measure, which is either BAC_Amount or BAC_Count, depending on the specification. I hypothesize that the coefficients on our auditor concentration measures are negative.

Additional control variables relating to the loan, auditor, and borrower are constructed using DealScan, AuditAnalytics and Compustat with descriptive statistics displayed in Table 1. As borrower quality affects loan terms, I attempt to control for differences in credit risk using loan-specific as well as borrower characteristics. Following prior literature, loan-specific controls include the amount of the loan in millions (Loan_Amt), the maturity of the loan in months (Maturity), and a dichotomous variable equal to one if the loan is secured, and zero otherwise (Security). Since some observations have missing data on whether a loan is secured, I also include an indicator variable equal to one if data is missing on whether the loan is secured, and zero otherwise (Miss_Sec).

Borrower-specific controls include the borrower's ratio of book value of leverage to total assets (BookLev), profitability defined as return on assets $(R O A)$, and creditworthiness measured using a transformation of S\&P long-term issuer (borrower) rating (SNP). The $S N P$ variable takes values of one to 24, increasing from most to least credit worthy. Firms with a Standard and Poor's (S\&P) long-term bond rating of "AAA" have a SNP value of one, while those with a "D" rating have a value of 24. However, not all borrowers have S\&P credit ratings. To control for this, I set SNP equal to zero for firms with missing S\&P ratings and include an indicator variable (Miss_SNP), which is equal to one if the firm has no bond rating, and zero otherwise. As I am looking to isolate the effect of bank-auditor concentration on loan spreads, I also control for auditor characteristics shown to affect borrowing costs in prior literature. I control for whether the borrower's auditor is a Big-4 auditor using an indicator variable (Big4), which is set equal to one if the borrower's auditor is a Big-4 auditor and zero otherwise. National expertise (NatExpert) is an indicator variable set equal to one if the borrower's auditor has the largest market share of U.S. public clients by audit fees within a two-digit SIC industry and zero otherwise.

To control for outliers, I winsorize all continuous variables at the $1^{\text {st }}$ and $99^{\text {th }}$ percentiles of the distribution. I also include industry fixed effects, based on Fama-French 12 industry classifications, to control for unobservable industry characteristics and year fixed effects to control for macroeconomic conditions. I cluster the standard errors by firm to adjust for serial-correlation.

Table 1 presents the summary statistics for the sample. The mean (median) values of BAC_Amount and BAC_Count are $0.17(0.18)$ and $0.14(0.14)$, respectively. This indicates that, on average, nearly one-fifth of loans issued by a lender are made to clients sharing the borrower's auditor. Given that 96 percent of the sample engages one of the "Big-4" audit firms, this percentage is not particularly surprising. The loans in the sample have mean (median) loan spreads of 125 (154) basis points over LIBOR, maturities of 52 (60) months, and loan amounts of \$490 (\$260) 
million. The borrowers in the sample have mean (median) total assets of $\$ 7.15(\$ 2.15)$ billion, return on assets of 3\% (4\%), and book leverage of 33 (31) percent of total assets.

Table 1. Summary Statistics

\begin{tabular}{llllll}
\hline & Mean & StdDev & 25 th & Median & 75 th \\
\hline Spread & 153.94 & 113.23 & 62.50 & 125.00 & 225.00 \\
BAC_Amount & 0.17 & 0.06 & 0.13 & 0.18 & 0.21 \\
BAC_Count & 0.14 & 0.05 & 0.10 & 0.14 & 0.17 \\
Size & 7.59 & 1.46 & 6.57 & 7.52 & 8.62 \\
LoanAmt & 490 & 631 & 120 & 260 & 588 \\
Maturity & 52 & 14 & 36 & 60 & 60 \\
Security & 0.45 & 0.50 & 0.00 & 0.00 & 1.00 \\
Miss_Sec & 0.25 & 0.43 & 0.00 & 0.00 & 0.00 \\
BookLev & 0.33 & 0.21 & 0.20 & 0.31 & 0.43 \\
ROA & 0.03 & 0.09 & 0.01 & 0.04 & 0.07 \\
Big4 & 0.96 & 0.20 & 1.00 & 1.00 & 1.00 \\
NatExpert & 0.34 & 0.47 & 0.00 & 0.00 & 1.00 \\
SNP & 7.08 & 5.61 & 0.00 & 8.00 & 12.00 \\
Miss_SNP & 0.33 & 0.47 & 0.00 & 0.00 & 1.00 \\
LeadArranger & 0.45 & 0.50 & 0.00 & 0.00 & 1.00 \\
\hline
\end{tabular}

Table 1 presents summary statistics for the sample $(\mathrm{N}=21,517)$ used in our primary analysis. Spread is the loan spread defined as basis points over the LIBOR rate; BAC_Amount is bank-auditor concentration weighted by loan amount; BAC_Count is bank-auditor concentration weighted by number of loans. Size is the natural log of total assets of the borrower, LoanAmt is the dollar value of the loan in \$millions; Maturity is the term of the loan in months; Security is an indicator variable equal to one if the loan is secured by borrower assets and zero, otherwise; Miss_Sec is an indicator variable equal to one if data on whether the loan is secured is missing in DealScan and zero, otherwise. BookLev is the ratio of the borrower's book value of leverage to its total assets; ROA is return on assets, defined as income before extraordinary items divided by total assets. Big4 is an indicator variable equal to one if the borrower's auditor is one of the Big-4 audit firms and zero, otherwise; NatExpert is an indicator variable equal to one if the borrower's auditor has the largest industry market share, by audit fees, of U.S. public clients; CityExpert is an indicator variable equal to one if the borrower's auditor-office has the largest industry market share of public clients in the auditor's city. SNP is a number corresponding to the borrower's S\&P credit rating with 1 being the lowest credit risk, 24 being the highest, and zero indicating that the borrower does not have a S\&P credit rating; Miss_SNP is an indicator variable equal to one if the borrower does not have an S\&P credit rating, and zero otherwise; LeadArranger is an indicator variable equal to one if the bank was a lead arranger for the syndicated loan, and zero otherwise.

\subsection{Main Results}

Table 2 presents the results of the regression of loan spread Spread on measures of bank-auditor concentration BAC_Amount and BAC_Count, controlling for other known determinants of loan spreads. In Column (1) of Table 2, the coefficient on BAC_Amount (-25.211) is negative and statistically significant $(\mathrm{p}<0.10)$, and in Column (2) the coefficient on BAC_Count (-33.704) is negative and statistically significant ( $\mathrm{p}<0.05)$. This supports the hypothesis that borrowers enjoy lower costs on loans when the lender's client-portfolio is more heavily concentrated among firms engaging their auditor. As far as economic significance is concerned, a six (five) percent increase (i.e., one-standard deviation) in the lender's portfolio by loan proceeds (count) that engages the borrowing firm's external auditor is associated with a 1.5 (1.7) basis point reduction for the borrowing firm. For the average loan in the sample, this corresponds to roughly $\$ 73,500$ (\$83,300) annual savings in interest (i.e. $\$ 490$ million x 1.5 (1.7) basis points). I interpret this amount as the incremental reduction in information gathering and monitoring costs on each loan stemming from the lender's relationship with borrower's auditor. 
Table 2. The effect of Bank-Level Auditor Concentration on Loan Spreads

\begin{tabular}{|c|c|c|c|c|}
\hline $\begin{array}{l}\text { Dependent } \\
\text { Spread }\end{array}$ & Variable $=(1)$ & & (2) & \\
\hline Intercept & $\begin{array}{l}129.499 \\
(7.55)\end{array}$ & $* * *$ & $\begin{array}{l}129.278 \\
(7.54)\end{array}$ & $* * *$ \\
\hline BAC_Amount & $\begin{array}{l}-25.211 \\
(-1.83)\end{array}$ & $*$ & & \\
\hline BAC_Count & & & $\begin{array}{l}-33.704 \\
(-2.35)\end{array}$ & $* *$ \\
\hline NatExpert & $\begin{array}{l}-1.179 \\
(-0.70)\end{array}$ & & $\begin{array}{l}-1.181 \\
(-0.70)\end{array}$ & \\
\hline Big4 & $\begin{array}{l}6.845 \\
(1.69)\end{array}$ & $*$ & $\begin{array}{l}6.468 \\
(1.60)\end{array}$ & \\
\hline Size & $\begin{array}{l}-3.750 \\
(-4.11)\end{array}$ & $* * *$ & $\begin{array}{l}-3.726 \\
(-4.09)\end{array}$ & $* * *$ \\
\hline LoanAmt & $\begin{array}{l}-0.007 \\
(-4.42)\end{array}$ & $* * *$ & $\begin{array}{l}-0.007 \\
(-4.40)\end{array}$ & $* * *$ \\
\hline Maturity & $\begin{array}{l}-0.416 \\
(-5.23)\end{array}$ & $* * *$ & $\begin{array}{l}-0.416 \\
(-5.23)\end{array}$ & $* * *$ \\
\hline Security & $\begin{array}{l}63.149 \\
(28.87)\end{array}$ & $* * *$ & $\begin{array}{l}63.085 \\
(28.85)\end{array}$ & $* * *$ \\
\hline Miss_Sec & $\begin{array}{l}19.962 \\
(11.03)\end{array}$ & $* * *$ & $\begin{array}{l}19.750 \\
(10.88)\end{array}$ & $* * *$ \\
\hline BookLev & $\begin{array}{l}97.492 \\
(17.55)\end{array}$ & $* * *$ & $\begin{array}{l}97.563 \\
(17.56)\end{array}$ & $* * *$ \\
\hline$R O A$ & $\begin{array}{l}-175.51 \\
(-13.66)\end{array}$ & $4 * * *$ & $\begin{array}{l}-175.444 \\
(-13.66)\end{array}$ & $* * *$ \\
\hline$S N P$ & $\begin{array}{l}12.538 \\
(26.31)\end{array}$ & $* * *$ & $\begin{array}{l}12.535 \\
(26.29)\end{array}$ & $* * *$ \\
\hline Miss_SNP & $\begin{array}{l}154.086 \\
(27.36)\end{array}$ & $* * *$ & $\begin{array}{l}153.996 \\
(27.34)\end{array}$ & $* * *$ \\
\hline \# of Obs. & 21,517 & & 21,517 & \\
\hline Adjusted $\mathrm{R}^{2}$ & $63.30 \%$ & & $63.31 \%$ & \\
\hline
\end{tabular}

Table 2 presents regression estimates for our test of the effect of auditor concentration on loan spreads. Column (1) uses a measure of auditor concentration (BAC_Amount) weighted by borrower assets while column (2) uses a measure of auditor concentration (BAC_Count) weighted by the total number of bank borrowers. All regressions include year fixed effects and standard errors are clustered by borrower. T-statistics are reported in parentheses below the coefficients and *,**, and *** denote statistical significance at the 10,5 , and 1 percent levels, respectively. See Appendix 1 for description of all variables.

\subsection{Additional Analysis}

Next, I test whether the observed effect between loan spread and bank-auditor concentration is stronger for banks that serve as the lead arranger in the syndicated loan. Lead arrangers bear the most risk in any given loan with multiple lenders. Consequently, I expect the informational value of bank-auditor relationships to have a larger effect on loan pricing when the issuing bank is a lead arranger. To test this, I construct a dichotomous variable, Lead_Arranger, set equal to one if the lender is the lead arranger in the syndicated loan and zero otherwise. The mean of this variable is 0.45 , corresponding to a total of 9,683 lender observations with the lead arranger role in the sample.

Table 3 presents the results of the regression of loan spread on bank-auditor concentration, the lead arranger indicator, and an interaction of the two variables. In Columns (1) and (2), the coefficients on BAC_Amount and BAC_Count 
respectively are not statistically significant, suggesting that the concentration of the lender's client-portfolio that engages the borrowing firm's auditor does not affect the borrowing firm's debt costs when lender is not the lead arranger. However, the coefficients on the interaction of Lead_Arranger*BAC_Amount (-51.518) and Lead_Arranger*BAC_Count (-51.573) in Columns (1) and (2) respectively are negative and statistically significant $(\mathrm{p}<0.01)$. This suggests that the benefits to the borrowing firm when its lender's portfolio is more heavily concentrated among firms engaging its auditor is isolated to loans where the lender is the lead arranger. This is consistent with the lead arranger's incentives in particular to gather information about the borrowing firm that can facilitate favorable terms. Regarding economic significance a six (five) percent increase (i.e. one standard-deviation) in Lead_Arranger*BAC_Amount (Lead_Arranger*BAC_Count) is associated with a 3.2 (3.2) basis point reduction for the borrowing firm. For the average lead arranger loan in the sample, this corresponds to roughly $\$ 131,840$ annual savings in interest (i.e. $\$ 412$ million $\times 3.2$ basis points).

Table 3. The effect of Bank-Level Auditor Concentration on Loan Spreads for Lead vs. Non-Lead Arranger Banks

\begin{tabular}{|c|c|c|c|c|}
\hline Dependent Variable $=$ Spread & $(1)$ & & $(2)$ & \\
\hline Intercept & $\begin{array}{l}108.581 \\
(6.17)\end{array}$ & $* * *$ & $\begin{array}{l}109.804 \\
(6.26)\end{array}$ & $* * *$ \\
\hline BAC_Amount & $\begin{array}{l}-0.991 \\
(-0.07)\end{array}$ & & & \\
\hline LeadArranger * BAC_Amount & $\begin{array}{l}-51.518 \\
(-3.50)\end{array}$ & $* * *$ & & \\
\hline BAC_Count & & & $\begin{array}{l}-14.332 \\
(-0.95)\end{array}$ & \\
\hline LeadArranger *BAC_Count & & & $\begin{array}{l}-51.573 \\
(-2.92)\end{array}$ & $* * *$ \\
\hline LeadArranger & $\begin{array}{l}18.856 \\
(6.89)\end{array}$ & $* * *$ & $\begin{array}{l}17.586 \\
(6.38)\end{array}$ & $* * *$ \\
\hline NatExpert & $\begin{array}{l}-1.149 \\
(-0.68)\end{array}$ & & $\begin{array}{l}-1.047 \\
(-0.62)\end{array}$ & \\
\hline Big4 & $\begin{array}{l}6.845 \\
(1.69)\end{array}$ & $*$ & $\begin{array}{l}6.468 \\
(1.60)\end{array}$ & \\
\hline Size & $\begin{array}{l}-3.438 \\
(-3.78)\end{array}$ & $* * *$ & $\begin{array}{l}-3.427 \\
(-3.76)\end{array}$ & $* * *$ \\
\hline LoanAmt & $\begin{array}{l}-0.007 \\
(-4.49)\end{array}$ & $* * *$ & $\begin{array}{l}-0.007 \\
(-4.46)\end{array}$ & $* * *$ \\
\hline Maturity & $\begin{array}{l}-0.386 \\
(-4.86)\end{array}$ & $* * *$ & $\begin{array}{l}-0.387 \\
(-4.86)\end{array}$ & $* * *$ \\
\hline Secured & $\begin{array}{l}62.979 \\
(28.90)\end{array}$ & $* * *$ & $\begin{array}{l}62.867 \\
(28.86)\end{array}$ & $* * *$ \\
\hline Miss_Sec & $\begin{array}{l}19.439 \\
(10.75)\end{array}$ & $* * *$ & $\begin{array}{l}19.159 \\
(10.55)\end{array}$ & $* * *$ \\
\hline BOOKLEV & $\begin{array}{l}96.883 \\
(17.52)\end{array}$ & $* * *$ & $\begin{array}{l}96.901 \\
(17.52)\end{array}$ & $* * *$ \\
\hline$R O A$ & $\begin{array}{l}-173.511 \\
(-13.60)\end{array}$ & $* * *$ & $\begin{array}{l}-173.607 \\
(-13.62)\end{array}$ & $* * *$ \\
\hline SNP & $\begin{array}{l}12.529 \\
(26.37)\end{array}$ & $* * *$ & $\begin{array}{l}12.528 \\
(26.36)\end{array}$ & $* * *$ \\
\hline Miss_SNP & $\begin{array}{l}153.585 \\
(27.37) \\
\end{array}$ & $* * *$ & $\begin{array}{l}153.503 \\
(27.36) \\
\end{array}$ & $* * *$ \\
\hline $\begin{array}{l}\text { \# of Obs. } \\
\text { Adjusted } R^{2}\end{array}$ & $\begin{array}{l}21,517 \\
63.53 \%\end{array}$ & & $\begin{array}{l}21,517 \\
63.53 \%\end{array}$ & \\
\hline
\end{tabular}

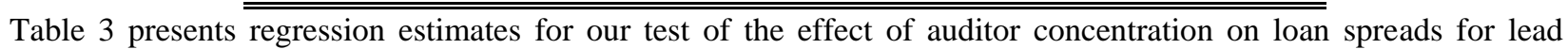
compared to non-lead arranger banks. Column (1) uses a measure of auditor concentration (BAC_Amount) weighted 
by borrower loan amounts while column (2) uses a measure of auditor concentration (BAC_Count) weighted by the total number of bank borrowers. LeadArranger is an indicator variable equal to one if the bank was a lead arranger for the syndicated loan, and zero otherwise. All regressions include year fixed effects and standard errors are clustered by borrower. T-statistics are reported in parentheses below the coefficients and *,**, and *** denote statistical significance at the 10,5, and 1 percent levels, respectively. See Appendix 1 for description of all other variables.

I also consider whether the relation between loan spreads and bank-auditor concentration occurs at the audit office level. Although I anticipate any private communication between the bank and auditor to occur at this more local level, it is unclear whether I will observe greater bank-auditor concentration translating to lower spreads here. For one, the number of clients in a bank's portfolio engaging any individual audit-office is far fewer than the number of clients engaging an individual auditor at the national level, providing fewer opportunities to observe relational banking. Second, it is possible the results I obtain in our main analysis reflect a bank's familiarity with the auditor's style, manifested at the national level, that allows it to better interpret the audited financial statements. This mechanism would not require private communication channels that plausibly involve illicit information sharing.

To test whether bank-audit-office concentration impacts loan spread, I modify our variables of interest to so that the numerator reflects the loan amounts or number of borrowers from a bank using a specific auditor-office. (Note 3) In untabulated analysis, I find no evidence that a higher concentration of a lender's client-portfolio engaging the borrowing firm's audit-office leads to lower spreads for the borrowing firm. Although this suggests a lack of private information sharing at the local level between the bank and audit-office, I cannot rule out that information transfer may take place at the national level or that restricting our sample to firms covered by Compustat, Audit Analytics, and Deal Scan limits our ability observe audit-office effects.

\section{Conclusion}

This study considers whether a lender's relationship with a borrower's external auditor through a shared client portfolio affects loan pricing. I find that a borrower's loan spread is negatively associated with the percentage of the lender's client portfolio, both by loan proceeds and by count, that engages the borrower's external auditor. In additional analysis, I find that this relationship exists only for lead arrangers, the lender primarily charged with gathering information about the borrower and bearing the greatest default risk. These findings suggest lenders acquire information about the borrowing firms' creditworthiness from the auditor and pass the savings from this information gathering to the borrower. I am unable to provide evidence that the reduction in information asymmetry occurs through the lender using its relationship with the auditor at the local level to directly solicit private information about the borrower. Instead, it is possible the lender uses its familiarity with the auditor's "style" at the national level to better interpret the borrower's audited financial statements. Overall, my findings contribute to the extant literature in accounting and finance by highlighting the importance of bank-auditor relationships to corporate financing outcomes. This study also contributes valuable information to potential borrowers using bank loans for financing. My findings inform borrowers that they may be able to achieve more favorable loan pricing when their prospective lender's loan portfolio is more heavily concentrated in clients engaging their external auditor.

\section{References}

Berger, A.N. \& Udell, G.F. (1995). Relationship lending and lines of credit in small firm finance. Journal of Business, 351-381. https://doi.org/10.1086/296668

Bharath, S. T., Dahiya, S., Saunders, A., \& Srinivasan, A. (2011). Lending relationships and loan contract terms. Review of Financial Studies, 24(4), 1141-1203. https://doi.org/10.1093/rfs/hhp064

Bharath, S., Sunder, J., Sunder, S. (2008). Accounting quality and debt contracting. Accounting Review, 83, 1-28. https://doi.org/10.2308/accr.2008.83.1.1

Cai, Y., Y. Kim, J. C. Park, H. D. White. 2016. Common auditors in M\&A transactions. Journal of Accounting and Economics, 61(1), 77-99. https://doi.org/10.1016/j.jacceco.2015.01.004

Chen, P.F., He, S., Ma, Z. \& Stice, D. (2015). The information role of audit opinions in debt contracting. Forthcoming, Journal of Accounting and Economics. https://doi.org/10.1016/j.jacceco.2015.04.002

Cheng, L., M. Cheng, D. Dhaliwal, S. Kaplan. (2015). Bank auditor information transfer and audit quality. Working Paper, University of Arizona and Arizona State University.

Dhaliwal, D.S., Lamoreaux, P.T., Litov, L.P. \& Neyland, J.B. (2016). Shared auditors in mergers and acquisitions. Journal of Accounting and Economics, 61(1), 49-76. https://doi.org/10.1016/j.jacceco.2015.01.005 
Elyasiani, E. \& Goldberg, L.G. (2004). Relationship lending: a survey of the literature. Journal of Economics and Business, 56(4), 315-330. https://doi.org/10.1016/j.jeconbus.2004.03.003

Engelberg, J., Gao, P. \& Parsons, C.A. (2012). Friends with money. Journal of Financial Economics, 103(1), 169-188. https://doi.org/10.1016/j.jfineco.2011.08.003

Francis, J.R., Pinnuck, M.L. \& Watanabe, O. (2014). Auditor style and financial statement comparability. The Accounting Review, 89(2) 605-633. https://doi.org/10.2308/accr-50642

Ivashina, V. \& Kovner, A. (2011). The private equity advantage: Leveraged buyout firms and relationship banking. Review of Financial Studies, 24(7) 2462-2498. https://doi.org/10.1093/rfs/hhr024

Johnstone, K.M., Li, C. \& Luo, S. (2014). Client-auditor supply chain relationships, audit quality, and audit pricing. Auditing: A Journal of Practice \& Theory, 33(4), 119-166. https://doi.org/10.2308/ajpt-50783

Kim, J.B., Song, B.Y. \& Tsui, J.S. (2013). Auditor size, tenure, and bank loan pricing. Review of Quantitative Finance and Accounting, 40(1), 75-99. https://doi.org/10.1007/s11156-011-0270-z

Kim, J.B., Song, B.Y. \& Zhang, L. (2011). Internal control weakness and bank loan contracting: Evidence from SOX Section 404 disclosures. The Accounting Review, 86(4), 1157-1188. https://doi.org/10.2308/accr-10036

Li, C., Xie, Y. \& Zhou, J. (2010). National level, city level auditor industry specialization and cost of debt. Accounting Horizons, 24(3), 395-417. https://doi.org/10.2308/acch.2010.24.3.395

Lou, Y. and Vasvari, F.P., 2013. The role of reputable auditors and underwriters in the design of bond contracts. Journal of Accounting, Auditing \& Finance, 28(1) 20-52. https://doi.org/10.1177/0148558X11421673

Mansi, S.A., Maxwell, W.F. \& Miller, D.P. (2004). Does auditor quality and tenure matter to investors? Evidence from the bond market. Journal of Accounting Research, 42(4), 755-793. https://doi.org/10.1111/j.1475-679X.2004.00156.x

Pittman, J.A. \& Fortin, S. (2004). Auditor choice and the cost of debt capital for newly public firms. Journal of accounting and economics, 37(1), 113-136. https://doi.org/10.1016/j.jacceco.2003.06.005

Sisli-Ciamarra, E. (2012). Monitoring by affiliated bankers on board of directors: Evidence from corporate financing outcomes. Financial Management, 41(3), 665-702. https://doi.org/10.1111/j.1755-053X.2012.01191.x

Ton, Karen. (2015). Do shared auditors improve audit quality? Evidence from banking relationships. Working Paper, Emory University. 
Appendix 1: Variable Definitions

\section{Dependent Variables}

Spread Loan spread defined as basis points over the LIBOR rate from DealScan

\section{Variables of Interest}

\begin{tabular}{ll}
\hline BAC_Amount & $\begin{array}{l}\text { Bank-auditor concentration, defined as the sum of total loan amounts of borrowers from a } \\
\text { given bank using a specific auditor divided by the sum of loan amounts of all borrowers for } \\
\text { that bank. See equation (1a) }\end{array}$ \\
\hline BAC_Count & $\begin{array}{l}\text { Bank-auditor concentration, defined as the number of borrowers from a given bank using a } \\
\text { specific auditor divided by the total number of borrowers for that bank. See equation (1b) }\end{array}$ \\
\hline
\end{tabular}

\section{Control Variables}

\begin{tabular}{ll}
\hline Big4 & $\begin{array}{l}\text { An indicator variable equal to one if the borrower's auditor is one of the Big-4 audit firms } \\
\text { and zero, otherwise, based on data from Audit Analytics }\end{array}$ \\
\hline BookLev & $\begin{array}{l}\text { The ratio of the borrower's book value of leverage to its total assets form Compustat ((dltt + } \\
\text { dlc) / at) }\end{array}$ \\
\hline LeadArranger & $\begin{array}{l}\text { An indicator variable equal to one if the bank was a lead arranger for the syndicated loan, } \\
\text { and zero otherwise }\end{array}$ \\
\hline LoanAmt & The dollar value of the loan in \$millions from DealScan \\
\hline Maturity & The term of the loan in months from DealScan \\
\hline Miss_Sec & $\begin{array}{l}\text { An indicator variable equal to one if data on whether the loan is secured is missing in } \\
\text { DealScan and equal to zero otherwise. }\end{array}$ \\
\hline Miss_SNP & $\begin{array}{l}\text { An indicator variable equal to one if the borrower does not have an S\&P credit rating, and } \\
\text { zero otherwise }\end{array}$ \\
\hline NatExpert & $\begin{array}{l}\text { An indicator variable set equal to one if the borrower's auditor has the largest market share } \\
\text { of U.S. public clients by audit fees within a two-digit SIC industry and zero otherwise. }\end{array}$ \\
\hline ROA & $\begin{array}{l}\text { The borrowing firm's return on assets defined as earnings before extraordinary items } \\
\text { divided by total assets (ib / at). }\end{array}$ \\
\hline Security & $\begin{array}{l}\text { An indicator variable equal to one if the loan is secured by borrower assets and zero, } \\
\text { otherwise. }\end{array}$ \\
\hline Size & The natural log of the borrower's total assets (at). \\
\hline SNP & $\begin{array}{l}\text { A number ranging from 1 to 24, corresponding to the borrower's S\&P credit rating, with } \\
\text { higher values indicating greater credit risk. A value of 1 corresponds to an "AAA" rating } \\
\text { and 24 corresponds to a "D" rating. The variable is set equal to zero if the borrower does not } \\
\text { have an S\&P credit rating. }\end{array}$ \\
\hline
\end{tabular}

Appendix 1 provides detailed variable definitions for the models used in this study. Compustat variable names are provided in parentheses where applicable. 
Appendix 2: Sample Selection

\begin{tabular}{|l|l|l|}
\hline Data restriction & Effect on sample & Remaining observations \\
\hline $\begin{array}{l}\text { Unique lender-borrower } \\
\text { observations }\end{array}$ & & 132,264 \\
\hline Maturity of loan > 1 year & $-4,883$ & 127,381 \\
\hline Revolving and term loans & $-50,406$ & 76,975 \\
\hline Agent credit for loan & $-48,490$ & 28,485 \\
\hline Syndication or sole lender & -147 & 28,338 \\
\hline Senior creditor & -266 & 28,072 \\
\hline $\begin{array}{l}\text { Average > 10 loans per year over } \\
\text { the last five years }\end{array}$ & $-5,325$ & 22,747 \\
\hline Loan observation > 10M & -515 & 22,232 \\
\hline City expert data available & -541 & 21,691 \\
\hline Data necessary for control variables & -174 & 21,517 \\
\hline
\end{tabular}

Appendix 2 provides the data requirements and the effects of the data requirements on my sample size. The final sample of 21,517 observations represents 5,517 distinct firms in all 12 Fama-French industries. The restrictions are described in further detail on pages 7 and 8 .

\section{Notes}

Note 1. AU-C Section 301.01-04

Note 2. This measure is also referred to as the all-in-drawn spread.

Note 3. We continue to define the denominator as the sum of loan amounts (total number) of all borrowers for that bank over a trailing five year period; however, when we define the denominator as the sum of loan proceeds (total number) of all borrowers for that bank in the borrower's city (i.e. Metropolitan Statistical Area "MSA"), our inferences remain unchanged. Since we shift our focus to the audit-office level, we modify our control for industry expertise so that it is calculated at the office-level, measured as an indicator variable set equal to one if the borrower's auditor has the largest market share by audit fees of public clients in the auditor's city (i.e. MSA) and zero otherwise. 